\title{
Texto y textura: el principio ecfrástico en Paseo de la identidad de Luis Bagué Quílez
}

Text and texture: the ecphrastic principle in Paseo de la Identidad by Luis Bagué Quílez

Giuliana Calabrese

Giuliana Calabrese es Doctora en Lenguas, Culturas y Literaturas Extranjeras por la Universidad de Milán. Actualmente es investigadora postdoctoral en la Universidad de Bérgamo y sus principales líneas de investigación son la poesía española contemporánea y las vinculaciones entre el discurso poético y el discurso plástico e intermedial. Desde septiembre 2020 es miembro del Proyecto de Investigación del Plan Estatal (I+D) "Poéticas de la Transición (1973-1982)", ref. FFI2017-84759-P (AEI/FEDER, UE).

Contato: siuliana.calabrese@gmail. com Itália 
PALABRAS CLAVE: Luis Bagué Quílez; Paseo de la identidad; Poesía española contemporánea; Écfrasis; Intermedialidad.

KEYWORDS: Luis Bagué Ouílez; Paseo de la identidad; Contemporary Spanish poetry; Ekphrasis; Intermediality.
Resumen: En este trabajo se analiza el poemario Paseo de la identidad (2014) de Luis Bagué Ouílez con un enfoque ectrástico desde las teorías estadounidenses sobre la intermedialidad. Se argumentará la elección de las obras de arte y los poemas ecfrásticos que, a partir de ellas, se construyen como un tratado panorámico que aborda la identidad - y quizás el sentido de humanidad occidental, que parece haberse perdido o vendido desde la época moderna.

Abstract: This work analyzes the book Paseo de la ldentidad (2014) by Luis Bagué Ouilez with an ekphrastic approach from the American theories on intermediality. The choice of works of art, and the ecphrastic poems that are built from them, will be argued as a panoramic discourse that addresses the Western identity - and perhaps the sense of humanity - that seems to have been lost or sold since modern times. 
Todas las épocas se han planteado interrogantes sobre el diálogo entre literatura y artes plásticas o figurativas, establecido tanto a través de prácticas artísticas propiamente dichas -muy a menudo resultado de sinergias intermediales- como por medio de respuestas críticas a obras de arte. El siglo XX se ha enfrentado a esta dimensión dialógica con la propuesta no solo de nuevos objetos interartísticos, sino también de nuevos posibles criterios de interpretación, que alimentan lo que James Heffernan llama "industria intelectual", en la mayoría de los casos de índole comparativa $(1993,1)^{1}$. Los estudios contemporáneos de cultura visual intentan alejarse de la tendencia logocéntrica y optan por dedicarse al estudio contextual de las imágenes y de su recepción. Dentro de esta tendencia caben las contribuciones teóricas que se dedican al estudio de la imagen y de las artes visuales o plásticas, así como a la de su repercusión en el sistema literario. Pueden mencionarse, por ejemplo, los trabajos centrados en el análisis de la forma interartística de la écfrasis - protagonista de este estudio-, como los de James Heffernan (1993) o

1 "Los críticos con una orientación empírica comparan textos específicos con específicas obras de arte visual; los críticos teoréticos tienen el objetivo de demostrar que podemos leer una obra literaria desde el punto de vista espacial, como si estuviéramos mirando una pintura, o interpretando un cuadro semióticamente como si fuera un texto, una red de signos verbales. Los críticos que plantean un trabajo comparativo desde uno de estos dos puntos de vista, suelen aspirar a romper las barreras teoréticas que Lessing (1960) levantó entre la poesía y las artes visuales: entre la poesía como un arte de signos convencionales que desfilan solitarios en el tiempo y la pintura como un arte de aparentes signos 'naturales' desplegados en el espacio. Pero sospecho que nos estamos acercando al final de lo que podemos aprender de estas formas artísticas hermanas gracias a una simple comparación entre ellas [...]. En mi opinión, las líneas de investigación más prometedoras en este ámbito [...] son las perfiladas por Iconology de W. J. T. Mitchell, estudio que aborda la relación entre literatura y artes visuales [...] como una lucha por la supremacía entre imagen y palabra” (Heffernan, 1993, 1). [Traducción mía] 
Thomas Mitchell $(2016,2017)$. Efectivamente, en las últimas décadas, la crítica estadounidense ha vuelto a poner de moda el análisis de esta figura retórica y se han dedicado innumerables páginas al concepto de ut pictura poesis, enfocándose además no solo en la relación entre literatura y artes visuales, sino ampliándola a la igual de eficaz intermedialidad con la fotografía y el cine.

Fue Murray Krieger (1992) quien revisó la écfrasis de modo más fructífero, como señala Carmen Fernández Klohe (2001, 29). En opinión de Krieger (1992), la predisposición de las artes figurativas es superar los propios límites miméticos del medio artístico y romper el cerco del contexto pictórico, escultórico, musical - abarcando la experiencia del receptor de la obra de arte. El objetivo principal de la literatura -y de la poesía de especial manera, como pone de relieve Krieger- es, por tanto, no solo ofrecer una descripción del objeto artístico, sino representar su presencia espacial y estática en lo que él define "principio ecfrástico", un lugar de resolución de la dualidad temporal-espacial de texto-imagen en un topos literario donde el lenguaje poético también adquiere plasticidad y espacialidad. En la "representación verbal de la experiencia visual" (Krieger, 1967, 7) -haciendo hincapié en la experiencia y no en el objeto-, el lenguaje poético trata de adquirir la misma sustancia matérica de la propia obra de arte, anulando el carácter temporal del lenguaje. Krieger (1967) profundiza el principio ecfrástico en relación a la figura del poeta, que, en el momento de escribir poesía, se vuelve crítico y acaba por explicitar tanto la referencia artística como el texto poético. Para que esto ocurra, hace falta que la obra literaria alcance una dimensión lingüística y formal capaz de convertir su progresión cronológica en simultaneidad y otorgar plasticidad al propio lenguaje verbal. 
Esta necesidad consciente por parte del poeta es la misma que, en opinión del crítico norteamericano, ha sustentado todas las teorías que, a lo largo de los siglos, han reflexionado acerca de la relación analógica o dialógica entre artes plásticas y literatura, desde el ut pictura poesis hasta la separación entre las artes promovida por Lessing (1960), quien indica que la poesía se amplía en el tiempo, mientras que el arte lo hace en el espacio. A través del filtro de Krieger, la écfrasis se convierte, por lo tanto, en instrumento que establece una relación entre el tiempo y el espacio de una obra literaria, gracias precisamente a la relación de esta última con las artes visuales.

En la literatura española ${ }^{2}$, esta figura retórica ha tenido especial énfasis en algunas épocas, como refiere Natalia Carbajosa (2013) destacando el peso de la poesía ecfrástica desde el Siglo de Oro hasta la época postmoderna:

la postmodernidad continúa con la ruptura emprendida en las vanguardias y transforma al poema ecfrástico en un objeto autosuficiente, desprendido del todo de su cualidad de ornamento del cuadro al que alude [...]. Es el período en el que el poeta se convierte, ante todo, en un cronista de museos que, en lugar de conformarse con los títulos y las explicaciones que acompañan a los cuadros, aporta su versión, a menudo antiecfrástica, de lo que allí percibe. [...] La poesía ecfrástica en Espańa, como es obvio, no ha sido inmune a esta influencia, y así nos encontramos con que autores como Jenaro Talens, José Ángel Valente o Pere Gimferrer exploran [...] esa tensión o resistencia ante la ruptura que es propia de la mirada postmoderna sobre la literatura y el arte. O con otros como Antonio Colinas, que ha hecho de su constante colaboración con artistas plásticos y de su poesía ecfrástica [...] una manera peculiar de entender la poesía y el arte. (Carbajosa Palmero, 2013, 209-10)

2 Pueden leerse, a este respecto, los trabajos editados por Francisco Díaz de Castro y Almudena del Olmo Iturriarte (2012) o la monografía de Luis Francisco García Martínez (2011), entre muchos otros. De indudable interés es la amplia bibliografía que recopilan. 
Resulta en especial modo pertinente la comparación que establece Natalia Carbajosa entre el poeta y el cronista de museos si hacemos referencia a Luis Bagué Quílez y a la "visita al Museo 3.0", que él organiza en casi todos sus poemarios y en su estudio La Menina ante el espejo, que también nos va a seguir de guía en este trabajo.

Desde el principio de su recorrido literario como poeta con Telón de sombras (2002), Luis Bagué Quílez (Palafrugell, Gerona, 1978) ha plasmado en sus textos una visión de la modernidad que refleja un mundo de estupor y desconcierto al mismo tiempo, para dedicarse, sobre todo en los últimos poemarios (Página en construcción, 2011, Paseo de la identidad, 2014 o Clima mediterráneo, 2017), a versificar una reflexión sobre el tiempo, la existencia y la cultura occidental. La solidez de este poeta de la primera generación del siglo XXI ha ofrecido desde los comienzos de su recorrido creador una serie de representaciones basadas en un análisis inteligente de la realidad, estudiada y poetizada desde un punto de vista desenfadado que, a lo largo de los años, ha ido adquiriendo una distancia irónica y complaciente a la vez. Su sujeto poemático es consciente de la existencia de 'pecados' que derivan de la poesía social y, para no caer en el maniqueísmo, se vacuna con la ironía o con el culturalismo. Si por un lado, su ironía adquiere los matices de instrumento de defensa o de subversión y reescritura del canon, definiéndose como un conjunto infinito de contrastes en el que se tensan las relaciones entre percepción e intelectualismo, por el otro, para alcanzar una progresiva independencia en la expresión de sus reflexiones, el sujeto ha ido adornándose y despojándose de elementos culturalistas. Sin embargo, se trata de referentes que, sobre todo al abordar temas tan graves como 
los migrantes que se enfrentan a "las ondulaciones bárbaras de un mar que quiso ser ilustrado” $(2017,55)$, demuestran la sensibilidad de no poder hablar apropiándose de la experiencia de otros, sino de la necesidad de expresarse desde la perspectiva de las vivencias propias. Por este motivo, en la solidez de su mundo poético y desde su doble condición de poeta y crítico, Bagué Quílez agrega la cultura de los museos a la enciclopedia de la vida y lo hace con una fuerte implicación ecfrástica del sujeto que deambula por los pasillos de sus poemarios, enfrentándose a las obras de arte allí reunidas. La perspectiva desde la cual miramos, tanto los lectores como el sujeto poemático, difiere en función de la educación, clase social e incluso nacionalidad, y ya no podemos permitirnos la ingenuidad o el lujo de pensar en un espectador neutro. Mitchell afirma que "si las imágenes nos enseñan cómo desear, también nos enseñan cómo ver, qué mirar y cómo organizar y crear un sentido de lo que vemos" $(2017,102)$. Si este objetivo ya presenta una gran complejidad en la aplicación directa a las obras de arte, al relacionarlo con un texto ecfrástico y, por lo tanto, con una mediación adicional, el interrogante es más profundo aún: ¿cuál es el sentido de estas imágenes que el sujeto poético de Bagué Quílez quiere que veamos a través de su mirada? ¿Por qué ha organizado una exposición de arte justo con estas obras?

Tanto Juan Carlos Abril (2014) como Francisco Díez de Revenga (2017) señalan un punto de inflexión en la poesía de Luis Bagué Quílez desde Paseo de la identidad (2014). Abril, en concreto, rememorando la paulatina separación del poeta de la línea experiencial, subraya en este poemario una “depuración” e indica que "marca un punto y aparte estilístico y estético, 
al transitar por un territorio de indagación que supone una adaptación y actualización de sus propios recursos formales" (Abril, 2014, 127). Ángel Luis Luján Atienza ve, en la publicación de este poemario, la "asunción de un riesgo" $(2016,169)$, al escribir un libro "que no quiere parecerse a sí mismo y pretende escapar, escurridizo, a su propia lectura, demostrando que toda lectura es traducción de un original perdido" $(2016,169)$.

\section{Paseo artístico hacia la búsQueda de Una IDENTIDAd}

En este artículo, nos enfocamos en la lectura del poemario galardonado con el XII Premio Emilio Alarcos como un tratado panorámico que, a través de referentes artísticos, aborda la identidad -y quizás el sentido de humanidad-occidental, que parece haberse perdido o vendido en la época moderna o contemporánea.

Empezando por el título, nos servimos de las palabras de Luján Atienza para señalar su apertura

a una significación desbordada. De un primer momento referencial (el Paseo de la identidad es un lugar geográfico convenientemente fotografiado en la portada) se pasa a una lectura metafórica doble por gracia del genitivo, pues en el sentido recto (posesivo) se trata de un paseo por la identidad, lo que genera a su vez una lectura metapoética: el libro es un deambular por diversos parajes de nuestro mundo global en un collage de voces, ecos de citas, reclamos publicitarios, en busca de una identidad, y es también un deambular de formas, estilos y tonos; sin embargo, entendido el genitivo como aposición obtenemos que "la identidad es un paseo": ya no hay búsqueda porque no hay objeto previo, la identidad se va creando precisamente en ese garbeo global. En esta línea, la gramática siempre ha ejercido a la perfección la posmodernidad. (Luján Atienza, 2016, 170) 
Paseo de la identidad, frente a la Plaza San Martín en Puerto Iguazú, es una colección de seis murales realizados con la técnica del esgrafiado, un procedimiento artístico utilizado por diferentes culturas antiguas entre las cuales los indios guaraníes, quienes originariamente poblaban la zona antes de la llegada de los españoles. Los seis murales que acogen al turista justo al llegar a Puerto Iguazú narran precisamente los orígenes del pueblo y despliegan el sentido de la historia que ha permitido llegar a la identidad presente. Por supuesto, el objetivo de este trabajo no es leer el poemario de Luis Bagué desde una perspectiva decolonial, pero no se puede olvidar que la colonización fue un proceso constitutivamente violento y que uno de sus primeros efectos fue la mundialización del sistema capitalista gracias al descubrimiento de nuevos recursos y nueva mano de obra (Dussel, 1994). El paseo de la identidad que se inaugura desde la portada del poemario, y con la imagen del cartel del lugar, es el que permite recorrer el proceso de civilización moderna y occidental empezando por la América profunda, para volver, después de un recorrido mundial y metafóricamente circular, al "origen del mundo", como veremos. Es un paseo artístico que aborda el alcance global de la modernidad europea empezándolo no desde los pasillos de un museo, sino a partir de la construcción artística de una memoria que además invierte el proceso de búsqueda de identidad: “ya no es Europa construyendo indígenas a partir de grandes civilizaciones, sino la memoria de las civilizaciones que vuelven" (Mignolo, 2010, 20). En la medida de este proceso, se afirma y se involucra la civilización occidental desde una perspectiva de subversión irónica del sentido. En este poemario, señala 
Luján Atienza, "La ironía, que anteriormente era un procedimiento digamos amable, un guiño cómplice al lector, alcanza aquí las cotas del sarcasmo o (invirtiendo la metáfora) baja a su infierno descarnado; la sonrisa está a punto de convertirse en mueca" $(2016,170)$.

\section{LA MECÁNICA TERRESTRE DE LA VIOLENCIA}

El "infierno descarnado" resulta tangible en la primera sección del poemario, "Mecánica terrestre": el orden global se rige en un mecanismo de consumo y violencia evidentes en las obras de arte a las que hace referencia Bagué Quílez, en su mayoría relativas al continente americano e inexorablemente adscritas al realismo. El doble encuadre de la lectura metarrepresentacional nos sitúa frente a los referentes artísticos que nos van a guiar durante la lectura del poemario. En el segundo poema del tríptico que abre el libro, "Oración en Starbucks", leemos lo siguiente:

Plegaria latte

(Acción de gracias)

Nunca será soluble la belleza.

Demos gracias

a los acantilados y al Laocoonte.

Al capitán Ahab y a la sombra de Bartleby.

A la gente naranja que en el 71 mordió la cinta roja del

primer café Starbucks del mundo, de Seattle.

Al tacto de los discos de vinilo. A las opas hostiles.

A las aves sonámbulas de Hopper bajo un cielo de avena.

A los trenes que paran incluso en Redford City. 
Texto y textura: el principio ecfrástico en PASEO DE LA IDENTIDAD de Luis Bagué Quílez

Al enfoque transgénico de los amaneceres.

A la sirena Starbucks tatuada en el tobillo.

A la sirena Starbucks que canta en ambulancias cheek to cheek.

A su blues: una cuerda pulsada hasta romperse.

No queremos retórica

envasada en un latte.

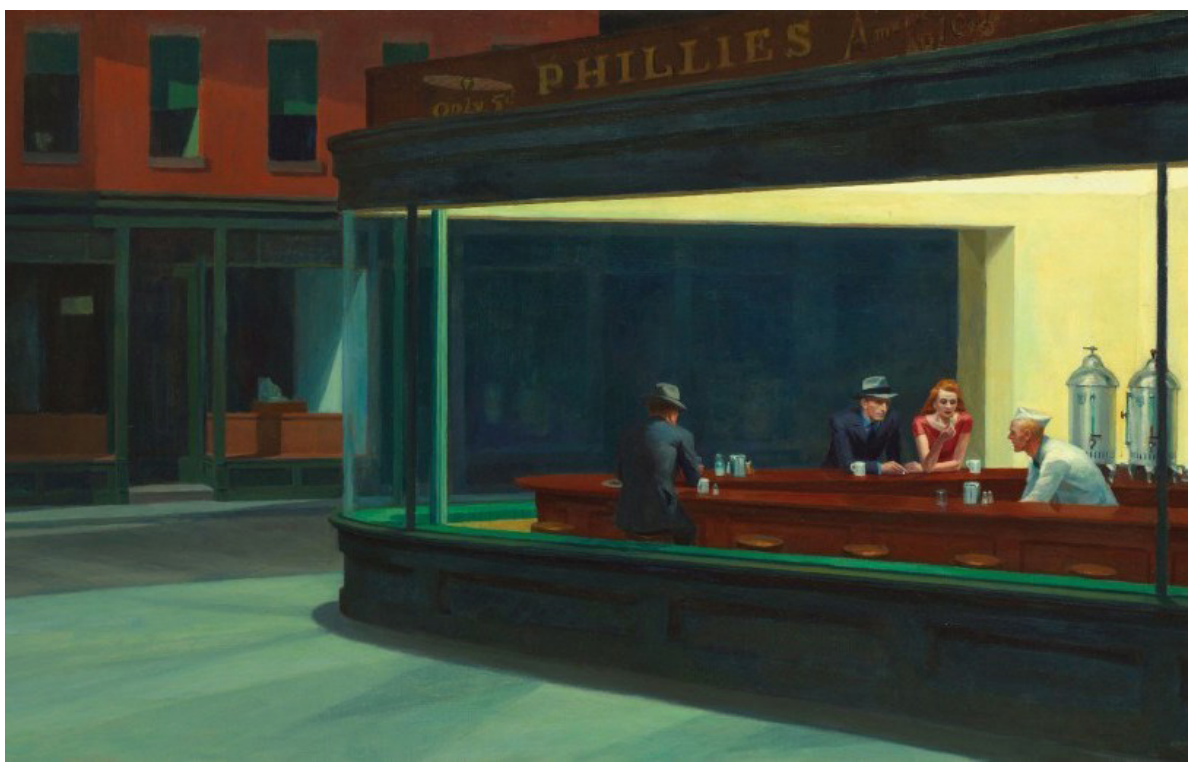

Figura 1 - Edward Hopper, Aves nocturnas, 1942

Óleo sobre lienzo. 84,1 ×152,4 cm

Fuente: The Art Institute of Chicaso

Con una desautomatización paródica del discurso litúrgico (cfr. Baños Saldaña, 2019), el poema nos sitúa en la famosa cadena de cafeterías 
que "se convierte por metonimia en dechado de la sociedad capitalista y en espacio abigarrado de mezcla (en el sentido cafetero) de lo viejo y lo inmediato, donde todo se reduce a un encuentro instantáneo y soluble [...] donde todo el mundo está de paso y toma decisiones provisionales para consumir en el momento (mocca o latte)" (Luján Atienza, 2016, 171). En el día de Acción de Gracias y en un claro contexto estadounidense, se enumeran elementos propios de la cultura occidental, tanto alta como de masas, que juegan con la sacralización de la modernidad. Las referencias que nos interesan en este momento son las artísticas, cuya belleza "Nunca será soluble" (v. 1) y, dejando de lado por un momento el personaje (y la representación) de Laocoonte, empezamos por el verso en que se menciona directamente el óleo de 1942 de Edward Hopper, Aves nocturnas (Nighthawks en su título original, fig. 1). En su brillante estudio La menina ante el espejo, Luis Bagué dedica varias páginas a lienzos del norteamericano, que ya se han convertido en tópicos visuales, y ofrece un listado de "cosas que se pueden hacer en un Hopper". En el punto 2 seńala: "remover el azúcar con la impostada lentitud de un autómata" $(2016,39)$. Los personajes de Hopper son muy semejantes al estado anímico del autómata y sus telas representan la patología común del desencanto de la clase media norteamericana. Colocados en el espacio de una cadena de cafeterías que "es el mundo" (Bagué Quílez, 2014, 9), siempre reconocibles y replicadas (¿o replicantes?), los consumidores nos vemos como los personajes del pintor estadounidense, que parecen haberse quedado sin un papel que desempeñar y sin un destino. 
El cuadro que el poeta está evocando es una representación exacta de la suspensión de lo real, de una espera sin esperanza que "ocurre en el momento en el que compartimos nuestra soledad con el resto de los personajes [...]. Son figuras inaccesibles al asedio retórico que, sin embargo, reclama su transparencia visual” (Bagué Quílez, 2016, 41). Al ser un poema surgido de la observación directa y de la rememoración de obras o referencias catalogadas en el archivo cultural colectivo, el juego con la iconografía nos coloca también en posición de observadores de esta galería personal y, observando el escaparate de la cafetería Phillies de Aves nocturnas, nos convertimos en voyeurs de una situación relativamente violenta: "la violencia implícita en los cuadros de Hopper reside en el propio acto de esperar, pues esperamos que algo suceda sabiendo que nada va a pasar” (Bagué Quílez, 2016, 41). Como si la incómoda sensación de asistir a una espera de este tipo no fuera suficiente, también miramos los cuadros de Hopper como a través de una cuarta pared (Bagué Quílez, 2016, 43). A partir de Aves nocturnas, el pintor pone en marcha un dispositivo fotográfico destinado a plasmar una "ficción de intimidad" que nos da la impresión de poder acercarnos a los personajes y que, por lo tanto, cuenta con nuestra participación como espectadores de la obra de arte, con la potencialidad para el poeta de poder inventarse una historia para sus silencios y con "propuestas de écfrasis [que] van más allá de la recreación de la escena” (Bagué Quílez, 2016, 47). 


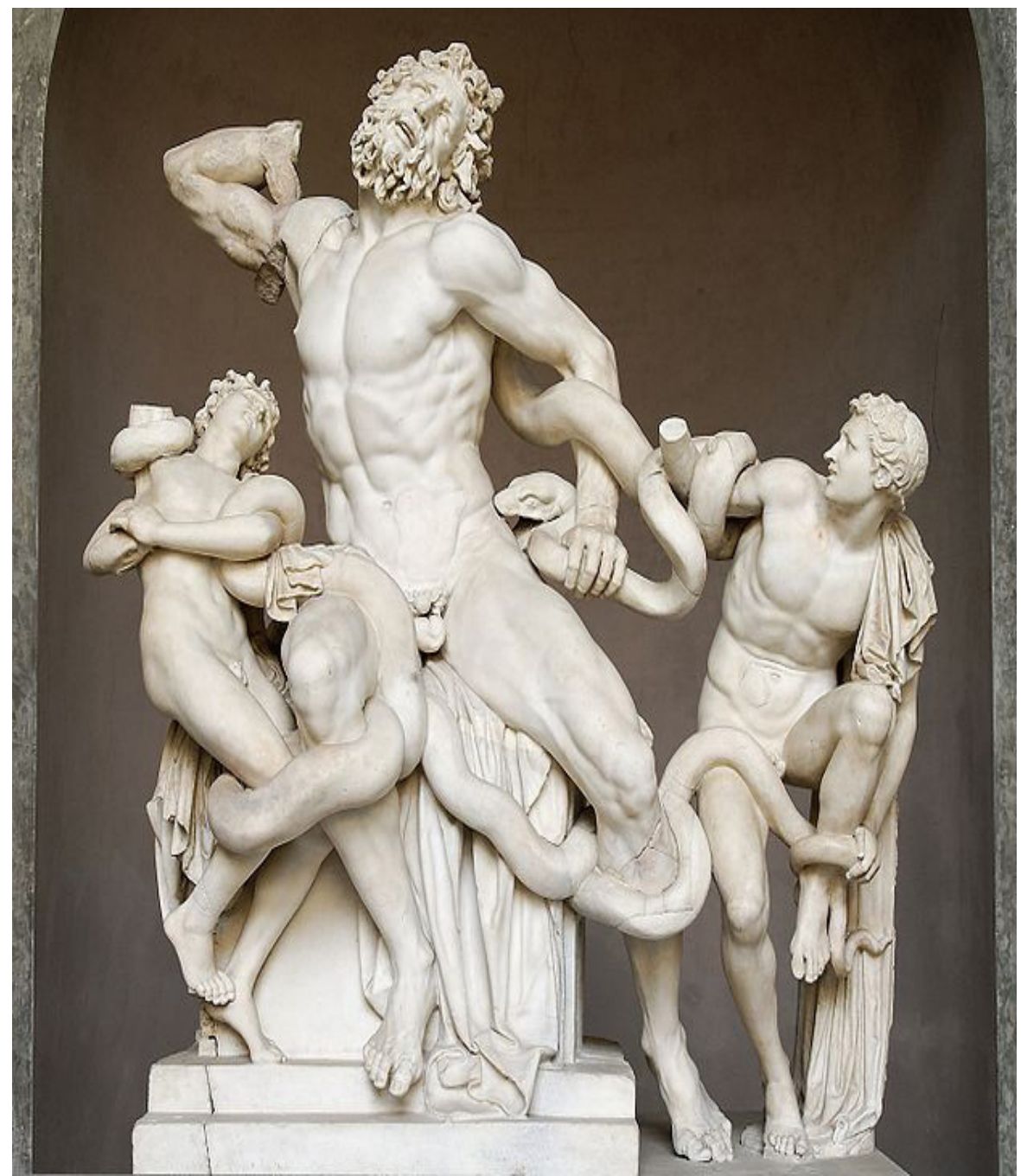

Figura 2 - Agesandro, Polidoro y Atenodoro de Rodas, Laocoonte y sus hijos, ca. s. I a. C. - s. I d. C.

(Probable copia de un orisinal de bronce de $150 \mathrm{a}$. C.)

Fuente: Museos Vaticanos 
Si "el presente en construcción de Hopper no admite ni un retorno al pasado ni una apuesta de futuro" (2016, 41), la referencia al Laocoonte (v. 3) parece enmendar esa falta, porque la alusión a las representaciones de ese personaje mitológico remiten al propio principio de la écfrasis de encerrar, en sí, pasado, presente y futuro. Las reflexiones de Lessing [1766], iniciadas precisamente a partir de las representaciones artísticas del episodio en que el personaje troyano pierde la vida junto con sus dos hijos, siguen constituyendo el punto de partida para los teóricos de la intermedialidad. A pesar de su argumentación sobre las barreras existentes entre la literatura y las artes figurativas, el punto de fuerza de la teoría de Lessing es lo que define einzigen Augenblick, el "instante único" (1960, 20), un "momento fértil” del que las artes plásticas se sirven para condensar los pasajes temporales de una vivencia y resumir en un momento e imagen únicos el pasado, el presente y el futuro del episodio mismo. La obra literaria que se apropia de esta extensión temporal de la obra de arte adquiere al mismo tiempo las capacidades de expansión no solo temporales, sino también espaciales de la obra de referencia. Para que esto ocurra, en opinión de Krieger (1967) -quien retoma, como la mayoría de los críticos, las teorías de Lessing como punto de partida de su argumentación, pero llegando a conclusiones casi opuestas- el texto poético tiene que convertir su dimensión de progresión cronológica en simultaneidad.

En su poema, Luis Bagué Quílez abre la colección de referencias culturales con la misma plasticidad con la que, en el texto virgiliano, 
entra en escena del personaje de Laocoonte, acompañado por un numeroso grupo de troyanos que lo apoya con una clara similitud con el coro de una tragedia. Virgilio ha introducido una innovación notable en el pasaje de la Eneida porque le ha dado una fisionomía marcadamente realista a un personaje que, en las fuentes mitológicas, solo era una sombra fugaz sin ninguna importancia. Su adversario, Sinón, convence a los troyanos para que introduzcan el famoso caballo de los griegos en la ciudad gracias a su retórica, a pesar de las mentiras de su discurso. Resulta pertinente la afirmación con la que Luis Bagué abre el dístico final de su poema: "No queremos retórica” (v. 14).

La tradición figurativa del mito de Laocoonte ha contribuido notablemente a la creación del trágico personaje virgiliano y ha hecho de su representación una de las imágenes que más estratificaciones tiene en la cultura occidental ${ }^{3}$. Volviendo al "momento fértil" elaborado por Lessing (1960), a propósito del grupo escultórico de Laocoonte, la recepción de la temporalidad en el espectador tiene un fuerte efecto por las relaciones internas que establece la figura: el padre, representante del momento presente, ocupa el centro del grupo y la dirección de su cuerpo muestra lo que está a punto de pasar. En su inclinación hacia el lado del hijo ya fallecido, se percibe su muerte

3 Laocoonte, sacerdote troyano que advirtió a sus conciudadanos que no admitieran el caballo de madera de los griegos en la ciudad, fue asesinado después con sus dos hijos. Relata Virgilio, en el "Libro Segundo" de la Eneida (2012), que, durante el sacrificio de un toro a Poseidón (no está claro si como ofrenda de agradecimiento por verse liberados del cerco griego o en un intento desesperado de provocar la muerte de estos últimos que estaban alejándose de Troya justo después de la entrega del caballo), salieron del mar dos serpientes que se enroscaron alrededor de Laocoonte y de sus dos hijos provocándoles la muerte. 
inexorable, mientras su pierna izquierda pierde el contacto con el suelo así como va a perder el contacto del mundo de los vivos, representado por su hijo todavía en vida a su izquierda. El hijo muerto y el vivo representan, respectivamente, el pasado y el futuro, mientras que las serpientes simbolizan el flujo del tiempo que une los tres momentos temporales. Los escultores que han realizado la obra se han detenido en el momento fértil del episodio: un punto en la línea temporal no atado al presente inmediato, sino dirigido hacia el futuro y recordándonos el pasado. La escultura no es una simple representación, sino que cuenta una historia que triunfa sobre las aparentes restricciones de la materialidad.

En la literatura y en el texto de Luis Bagué, Laocoonte es el símbolo de un fracaso momentáneo de la historia ${ }^{4}$, gracias al cual, sin embargo, será posible la afirmación de un sistema ético y de una estirpe futura en

4 En el poema hay dos referencias más a personajes supuestamente fracasados, que no forman parte de este análisis ecfrástico y que, sin embargo, resultan pertinentes en el acercamiento de Luis Bagué a la modernidad. Más allá de enlazar la cadena Starbucks a Melville, ya que Starbuck es el nombre del primer oficial del Pequod en Moby Dick, se sabe que Bartleby es el personaje del famoso I would rather not to, mientras que el capitán Ahab también emplea la desautomatización de fórmulas litúrgicas en su ritual de bendición del arpón con el que quiere vengarse de Moby Dick en un ritual casi satánico. La fórmula bautismal típica de la liturgia se convierte en la novela de Melville en "Ego non baptizo te in nomine patris, sed in nomine diaboli" (1994, 70), pero las relaciones con el mundo moderno que está poetizando Luis Bagué pueden extenderse a las teorizaciones marxistas que ven, en el arquetipo del monstruo (en la literatura gótica, por ejemplo), las ansias desmedidas del capitalismo (cfr. Moretti, 1982). "Cuando Melville se hallaba en plena fase de composición de la novela (1850) era muy consciente de las múltiples amenazas que se cernían sobre Estados Unidos: la esclavitud, las guerras expansionistas y la lucha de clases y la suya es una crítica explícita al imperialismo: 'El país del optimismo de fundación, la única nación que inscribe el derecho a la felicidad en su Constitución, iban acompañados desde el principio por la pesadilla americana, la literatura crítica negatoria de la inocencia proclamada mil veces y perdidas otras tantas"” (Rodríguez Herrera, 2014). 
Roma gracias a la huida de Enea, posibilitada por el sacrificio del propio Laocoonte (Virgilio, 2012). Es probable, por lo tanto, que Luis Bagué no utilice en sentido irónico la resemantización de la Acción de Gracias estadounidense del título, sino que sus agradecimientos a lo que estas figuras han hecho posible sean auténticos. Claro está que la escala de referencias desciende desde un punto cultural y moral máximo a una sacralización de la cultura media del consumismo y, en este descenso, se nota cómo la "acción de gracias" adquiere matices cada vez más subvertidos e irónicos.

Volviendo a los cuadros de Edward Hopper, pero dando un pequeño salto hacia la sección "Escala real" del libro, el poeta plasma en verso la historia que podría existir dentro de otro de los espacios del pintor, "el decorado de una road movie sin más destino que el viaje” (Bagué Quílez, 2016, 53). La fascinación por las posibilidades narrativas que residen en el cuadro sustituye el recurso clásico de la écfrasis descriptiva, con una reflexión sobre lo que hace del cuadro -y sobre la pintura de Hopper- una pieza emblemática. Ocurre en el poema 'Área de servicio':

La permanencia tiene perfiles transitorios.

Hopper revisitado: surtidor con autómata.

Ha elegido carburante sin plomo. Buen viaje.

El breve texto hace referencia a la tela Gasolina de 1940 (fig. 3). 
Texto y textura: el Principio ecfrástico en PASEO DE LA IDENTIDAD DE Luis Bagué Quílez

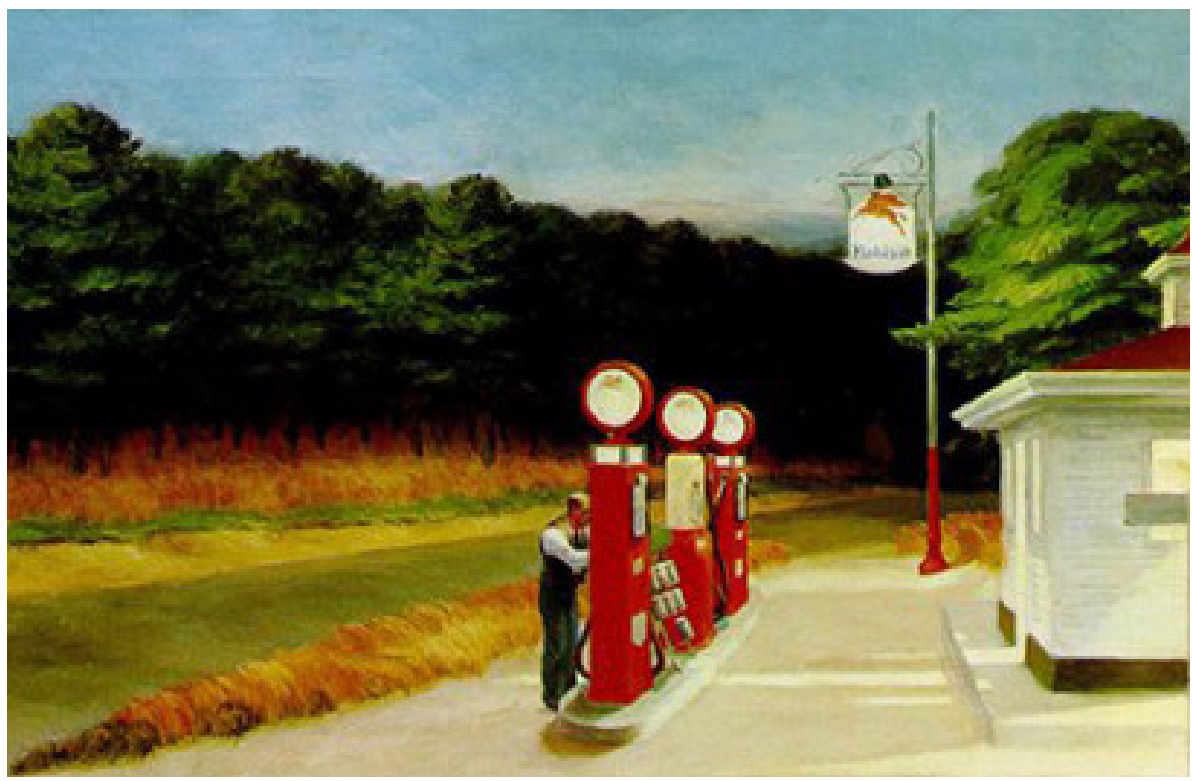

Figura 3 - Edward Hopper, Gasolinera, 1944

Óleo sobre lienzo. $66,7 \times 102,2 \mathrm{~cm}$

Fuente: MoMA - Museum of Modern Art

Mark Strand, al describir el cuadro, se detiene en la arboleda, "lista para tragarse al observador" $(2008,55)$, y explica qué elementos atraen la mirada de este último. A pesar de la falta de voluntad de Bagué Quílez de limitarse a poetizar una descripción del lienzo, siguiendo el "principio ecfrástico" teorizado por Krieger (1967), podemos apreciar que la estructura del poema replica la forma en la que están distribuidos los pocos elementos de la tela. El alexandrino inicial nos introduce en el espacio poético y también pictórico: en el lugar de tránsito de la estación de servicio, los 
únicos elementos permanentes son una arboleda y un lugar silencioso, sin los coches que justifican su existencia, pero los árboles con sus perfiles siguen siendo permanentes hasta que la civilización no los alcanza. Sin embargo, es verdadero también lo contrario: la mecanización puede resultar temporal en un contexto donde la naturaleza acecha y

la inmensidad panorámica y abrumadora del siglo XIX -el teatro de lo sublime en la narrativa de Herman Melville- muestra ahora su reverso introspectivo. Hopper mantiene una relación ambivalente con un paisaje que no puede concebir al margen de las señales que el progreso ha dejado en él. O bien está interrumpido por los hitos de la civilización industrial, o bien está amenazado por la vastedad de una naturaleza intacta. (Bagué Quílez, 2016, 54)

De todas formas, el telón de fondo de los árboles y la transitoriedad permanente que simbolizan son lo primero que capta la atención del observador, mientras que el extenso verso inicial de Luis Bagué nos sitúa en la línea recta de la parte superior del cuadro, favoreciendo además la sensación visual de paso por un recorrido recto y largo. La transitoriedad no se debe solo a la reflexión sobre el contraste entre condición silvestre y mecanizada, sino que se enfatiza su percepción visual y mental gracias a la extensión del verso. A lo largo de las sílabas y de la falta de puntuación, leemos y visualizamos "los árboles de Hopper [...] tal como suelen verse los árboles cuando pasamos junto a ellos a ochenta o cien kilómetros por hora" (Strand, 2008, 54). Los dos siguientes heptasílabos, "Hopper revisitado / surtidor con autómata", acompañan nuestra mirada desde la izquierda hacia la parte central del cuadro, haciendo que la atención se focalice en 
la combinación de bombas de gasolina y empleado que atiende la pequeña estación. Los bloques de versos y las líneas en blanco del texto replican el esquema visual del lienzo y la disposición de sus elementos, pero, a esta re-creación ecfrástica, añade Bagué Quílez la reflexión sobre los hombresautómatas de Hopper, que ya resultaba evidente en su argumentación teórica sobre la tela Aves nocturnas (2016, 39). Después de la parada en la gasolinera, tanto visual como métrica, el texto se cierra con otro alexandrino que confirma su papel de guía de la mirada del receptor y de elemento que enfatiza su condición de ser temporal. Si la observación del óleo nos lleva a detenernos en el punto de fuga debajo del letrero luminoso, formado por el corredor de los elementos pictóricos, el verso que cierra el texto no nos deja ninguna duda como viajeros sobre el destino que nos espera: en la primera parte del verso se reproduce lo que podría decir el empleado de la gasolinera, pero con una construcción irónica parecida a la voz metálica que surgiría de cualquier cajero automático. Vuelven a empezar nuestro viaje y nuestra espera hacia la nada. La habilidad del poeta en re-crear con la elección de sus versos la disposición espacial de los elementos del cuadro - además de otorgarle un soporte narrativo confirma la connotación que la écfrasis adquiere a través del filtro teórico de Krieger (1967, 5), cual expediente retórico que garantiza la plasticidad y la espacialidad de la temporalidad literaria y la "metaforización espacial de la verbalidad" (Hagstrum, 1958)5.

5 Además, para Hagstrum, son poemas ecfrásticos solo aquellos en los que se le da voz a una pintura o escultura muda, siendo estos poemas distintos de los que llama "icónicos", aquellos 
En su prólogo a la edición española de Hopper de Mark Strand, mencionando al propio poeta canadiense, Juan Antonio Montiel recuerda que "cuando Hopper pinta, sus 'representaciones realistas de escenas de la cotidianidad urbana conducen al observador al reconocimiento de la extrańeza de entornos aparentemente familiares' [Strand, 2007]" (Montiel, 2008 , 8). Dentro de la misma tendencia realista norteamericana, pero lejos de la textura onírica de Hopper, leemos otros referentes visuales en los que se apoya Luis Bagué Quílez para escribir los dos poemas reunidos bajo el título común "Teoría del retrato" (2014, 13-15). Después del pequeño viaje por carretera que nos condujo a la gasolinera de Hopper, estamos volviendo a la primera sección del poemario "Mecánica terrestre" y a las obras de arte americanas que decoran sus pasillos. El primero de los dos poemas de "Teoría del retrato" recibe el título de la obra de arte visual en la que se inspira, esta vez una serie de fotografías de Bill Owens.

en los que el poeta "contempla una obra de arte real o imaginada que describe o con la que, de alguna forma, crea una correspondencia” (1958, 18, traducción mía). De momento, no queremos limitar el procedimiento ecfrástico empleado por Bagué Quílez a este precepto de Hagstrum, pero es evidente que su hipótesis resulta muy fecunda si la aplicamos a los poemas que se enlazan con los cuadros de Hopper, ya que el pintor "se inscribe en la órbita de los grandes silencios americanos. [...] Los lienzos de Hopper no solo certifican la poesía muda con la que Simónides de Ceos identificaba a las artes plásticas. Además, dan fe de una suerte de conversión imaginativa. Conforme nos adentramos en sus óleos, crece 'el silencio que acompaña nuestra observación' [Strand, 2008, 109], a la vez que aumentan la suspensión y el desequilibrio. Sus paisajes no se conforman con no evocar ninguna fuente de sonido, sino que pretenden enfatizar el contenido dramático que transmiten esas imágenes silentes" (Bagué Quílez, 2016, 54-55). 


\section{Suburbia 1973}

(Bill Owens, San José Museum of Art)

Encontraste un lugar

perfecto para toda la familia.

Un eucaliptus rojo y un poste de teléfono.

Dos estilos de vida.

El árbol genealógico de la posteridad.

Ahora puedes

desplegar la moqueta, dar la vuelta

al polo positivo de las cosas:

los niños junto al Pontiac

blanco para la foto (polaroid automática),

en el mástil banderas Jasper Johns,

la cicatriz geológica de un centro comercial.

En un proyecto civilizatorio

nada debe sońar a la intemperie.

Suburbia es un proyecto del fotógrafo que, a lo largo de los años, se ha convertido en uno de los cronistas más irónicamente despiadados de la clase media norteamericana. La serie de fotografías de la vida de la urbanización de Sunsetown (California) tomadas por Bill Owen entre finales de los sesenta y 1973 retrata la realización del sueño americano de muchas familias que habían confiado en un American way of life: pequeños chalets parecidos el uno al otro, homes sweet homes, un buen coche, frontyards artificiales y un ambiente donde poder tener una familia en la tranquilidad de un lugar sin historia. Es probable que en su poema Luis Bagué no remita 
a una fotografía en concreto, sino a la exposición en el San José Museum of Modern Art, primero, y al libro que a partir de ese proyecto de Owens se publicó en 1973 y en el que se recoge la mayoría de las instantáneas. La falta de un título exacto en el texto de Luis Bagué nos permite esta interpretación, ya que un indicio de la irónica genialidad del fotografo fue pedirles a los personajes retratados que pusieran un título a la imagen en que se inmortalizaban. Hay resultados sorprendentes, como los siguientes:

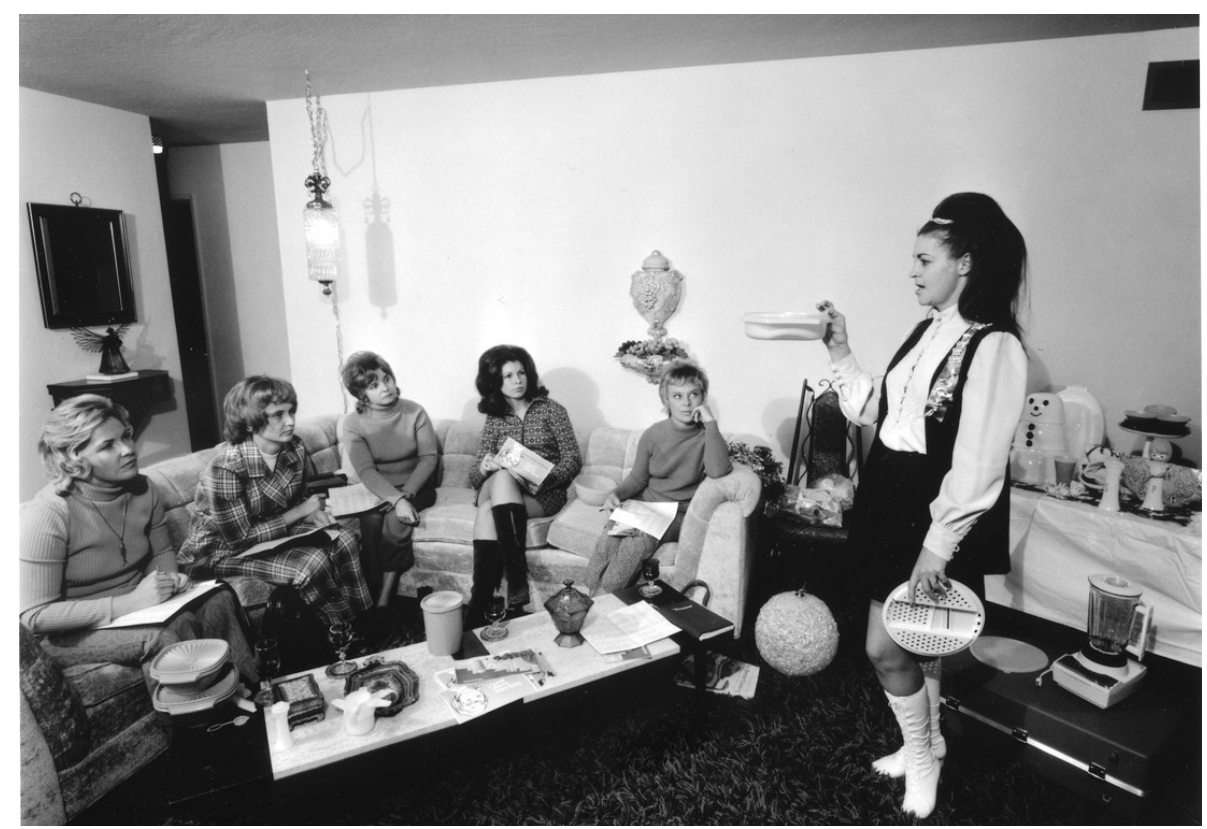

Figura 4 - "l enjoy giving a Tupperware party in my home. It gives me a chance to talk to my friends. But really, Tupperware is a homemaker's dream, you save time and money because your food keeps longer."

Bill Owens, Suburbia, 1973 Fuente: (C) Bill Owens Archive 
Texto y textura: el Principio ecfrástico en PASEO DE LA IDENTIDAD DE Luis Bagué Quílez

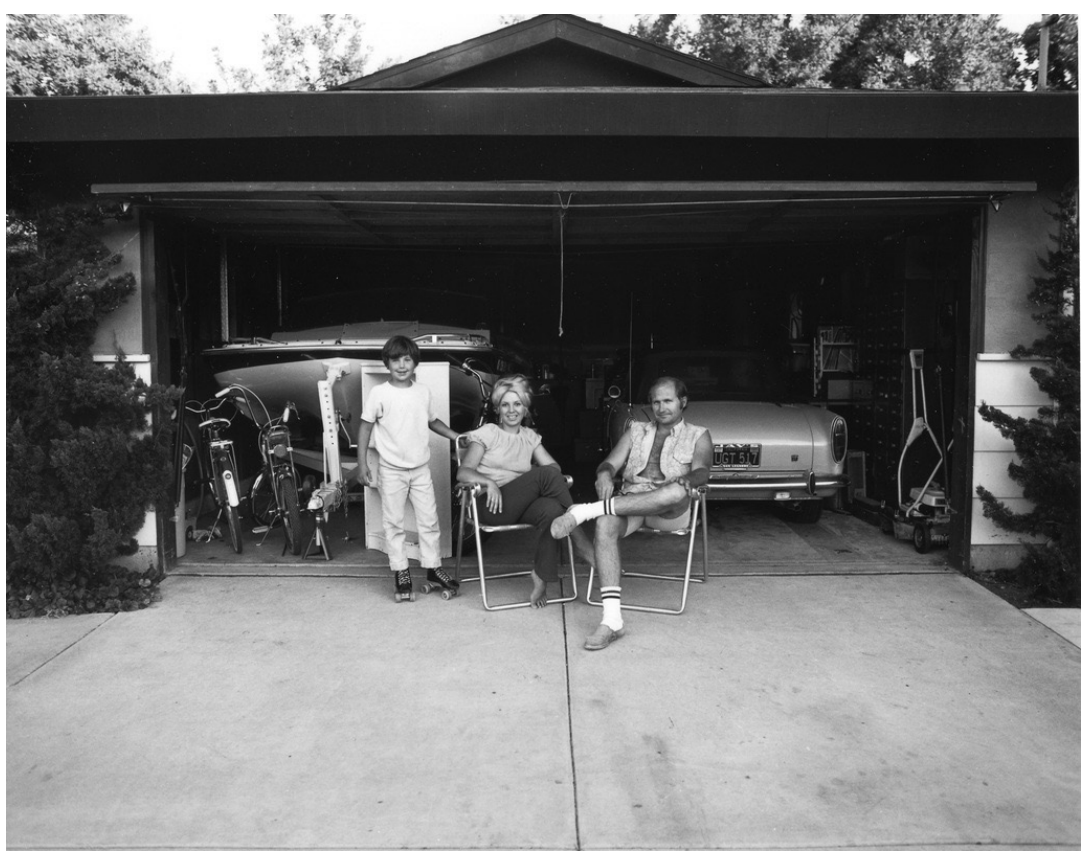

Figura 5 - "Our house is built with the living room in the back, so in the evening we sit out front of the garage and watch the traffic go by."

Bill Owens, Suburbia, 1973

Fuente: CBill Owens Archive

La germinación asociativa que se demuestra en los versos -y la capacidad proyectiva de la lente fotográfica y de la mente del poeta- adscribe el poema a la inversión de los parámetros ecfrásticos contemporáneos con los que se traduce una obra de arte al lenguaje literario. En estos versos, Bagué Quílez hace lo opuesto de lo que se espera del procedimiento de la écfrasis: no solo reconstruye poéticamente el conjunto fotográfico original, sino que lo deconstruye con una mirada irónica sobre los personajes retratados, extendiéndola al "proyecto 
civilizatorio" (v. 13) de la "identidad" a la que estamos acostumbrados. En opinión de Harold Bloom (1979, 25-26), esta inversión ha de contemplarse precisamente en clave irónica. Para ser más exactos y para volver a acercarnos a las teorías sobre la figura retórica en cuestión, se trata de una ironía en segundo grado, según la pista que ofrece el propio Bagué Quílez: "esta clase de ironía rompe con la distribución normativa que Lessing había establecido en su Laocoonte, según la cual las artes plásticas debían centrarse en los aspectos espaciales de la realidad, en tanto que la literatura debía plasmar la sucesión cronológica" (2016, 117). El núcleo expresivo establecido en el poema trasciende la "movediza quietud asociada con la fotografía" $(2016,118)$ y se ofrece como correlato de unas imágenes en cuyo collage se perfila el retrato del consumidor occidental medio, al que se dirige directamente la voz poética con un discurso irónicamente tranquilizador sobre su descendencia y la civilización para la que está sentando las bases.

Sigue esta teorización del retrato del consumidor con el segundo poema del díptico, también inspirado en una obra visual realista y donde, asimismo, la identidad por la que estamos paseando parece seguir en venta, pero esta vez con un sentimiento de más resignación percibido en la voz poética. Volvemos a una referencia pictórica con el lienzo de Robert Bechtle, Olympia (1977), que Bagué Quílez poetiza con un recurso ecfrástico:

\section{Olympia 1977}

(Robert Bechtle, SFMOMA)

Recuperar

el aura: 
Texto y textura: el Principio ecfrástico en PASEO DE LA IDENTIDAD de Luis Bagué Quílez

la inocencia

de lo que ya no puede repetirse.

Camiseta naranja, shorts

azules, la luz

descolorida tras las gafas

de sol.

Nos brinda el primer sorbo

de una cerveza

Olympia.

Los listones del suelo

y la retícula

del parterre y el césped

recién cortado

son distintas maneras

de zanjar

la eterna discusión.

Olympia fin de siglo,

redimida por la

escenografía:

nueva demi-mondaine

en pantalones cortos.

No hay más de lo que ves.

$\mathrm{Ni}$ rastro

de ironía, ni sombra

de argumento.

(Bagué Quílez, 2014, 14-15) 


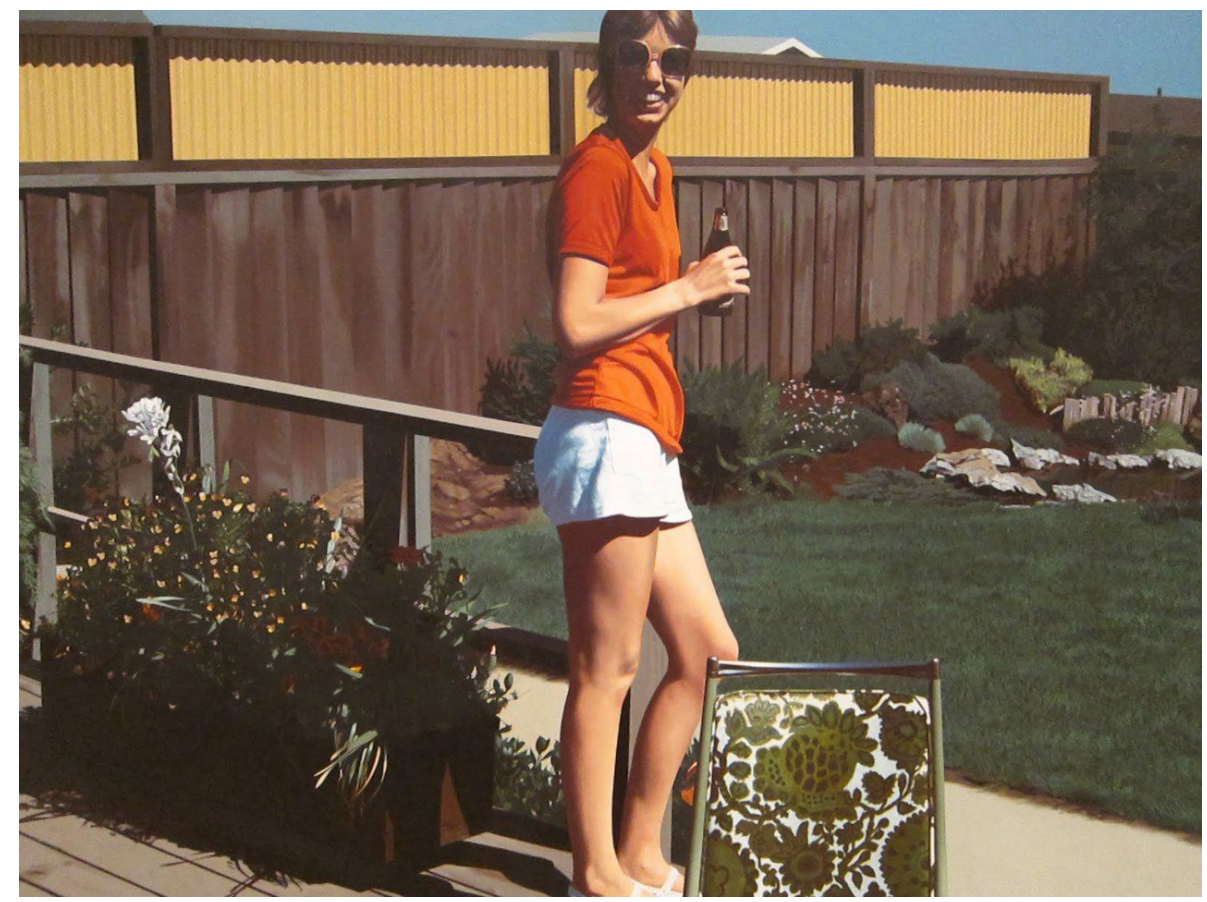

Figura 6 - Robert Bechtle, Watsonville Olympia, 1977

Óleo sobre lienzo. 121,9 × 175,3 cm

Fuente: San Francisco Museum of Modern Art

Representada en un momento de su cotidianidad con impresionante realismo, hasta el punto de que, a simple vista y a una mirada poco atenta, podría parecer una fotografía, en el cuadro de Bechtle la joven mujer sorprende por su naturalidad. En la actitud y en la sonrisa de Olympia, la mayoría de los consumidores estadounidenses se reconoce, y su botella de Oly beer nos la hace mucho más cercana. La postura del pintor es ambigua 
y no se entiende muy bien dónde acaba la provocación y dónde empieza la aceptación de los productos humanos y culturales de la civilización de las masas. A pesar de la falta de voluntad por parte de Bechtle de establecer una relación con la homónima obra de Manet (Shannon, 2017, 215), es inevitable la conexión con el lienzo del impresionista (Olympia, 1863), explicitada en la cuarta estrofa del poema de Bagué Quílez: la demi-mondaine de Bechtle se redime gracias a la escenografía que la acoge y al ambiente de consumo en que vive. Si la Olympia de Manet recibió, en su momento, muchas críticas por la referencia explícita al mundo de la prostitución, la Olympia de Bechtle es redimida, en palabras de Bagué Quílez, pese a haber vendido su identidad - y no solo su cuerpo, como en el mundo parisino del impresionista - a su entorno. Una vez más, gracias a la ambigüedad de Bechtle, tiempos y espacios se unen en la atención que transforma las habitaciones del pintor y del poeta en un único estudio, haciendo del cuadro y del texto un espejo en que el observador-lector se ve retratado. La identidad del consumidor parece haber perdido la capacidad de elaborar verbalmente su ambiente, como demuestra la lapidaria brevedad de los versos, y solo lo re-presenta haciendo más extenso también el concepto benjaminiano de aura que abre el texto. Luis Bagué lo está ampliando porque, está claro, no hay una reproducción directa del original, y ni siquiera copias, pero, con su alusión a Benjamin, adscribe involuntariamente las tres Olympias a una "familia de auras", según la definición de Augustín Fernández Mallo. En su Teoría general de la basura (2018), empezando precisamente por una reflexión sobre cómo nos vemos en un espejo, en un retrato o en una fotografía, que no son copias exactas 
porque nos crean "en otro lugar" (nos re-crean en el papel de plata, en el lienzo o ahora en una pantalla), Fernández Mallo teoriza

algo mucho más complejo que la simple copia o el simple original, se trata del entrelazamiento de ambos, un nudo de copias que conservan parte del aura del original pero dotadas del suficiente residuo como para erigirse ellas mismas en diferentes entre sí [...]. Algo se transmite de cuerpo a cuerpo y algo radicalmente cambia. [...] Todo ello tiene que ver con uno de los principales temas de preocupación de las sociedades contemporáneas: la identidad, esa alucinación del ego en tanto no existe como tal, sino como una multiplicidad de copias distinguidas por su correspondiente familia de auras. [Este tipo de copias] hablan por una parte de la pérdida de la metafísica aura del original, pero al mismo tiempo, en tanto nuevos originales, de la adquisición de una renovada aura que - y aquí está lo novedoso - no es metafisica sino relacional: la gestión de su significado viene establecida a través de los lazos con las condiciones estéticas y sociológicas del nuevo entorno de la obra, así como con los lazos con el que fuera el presunto objeto original. [...] A partir del juego y la ironía crítica, se destruye la sacralización del objeto artístico pero para dar forma a algo útil y relacional: la posibilidad de que la obra genere una familia de auras a través de sacrílegas traslaciones de sentidos, profanaciones. (Fernández Mallo, 2018, 247-248)

La familia de auras que se ha generado con la referencia a la Olympia impresionista nos conduce a la última sala de la primera sección. Seguimos en el continente americano, pero volvemos a la Argentina desde la cual había empezado nuestro paseo de la dentidad. La postura de la protagonista del lienzo de Manet, presente solo gracias a las referencias intertextuales que se han generado, recuerda la postura de la mujer que Antonio Berni retrata en su obra Sin título (1981). Bagué Quílez nos está presentando el apartado quizás más violento de su colección, titulado "Narrativas argentinas”. Es un 
tríptico $^{6}$ que se abre bajo el epígrafe "Antonio Berni en el MNBA" (2014, 20), que aclara la referencia a una exposición de obras del pintor argentino realizada por el Museo Nacional de Bellas Artes de Buenos Aires en 2010. En La menina ante el espejo (2016, 29-35), el poeta relata de forma detallada su visita a la retrospectiva y la interpretación de los óleos que recrea en sus versos: si los cuerpos y los personajes representados en las obras y en los poemas que hemos analizado hasta ahora han cedido sus propias capacidades verbales a los silencios de la modernidad, los cuerpos de Berni no hablan sino con su presencia porque el contexto en el que se encuentran es de absoluta indecibilidad. En el aparato represivo de la Argentina de la dictadura y de la desaparición, esos cuerpos presentan una ausencia, hacen tangible la modernidad llevada a su extremo, donde, sí, es evidente el mito irracional de la violencia genocida para autojustificarse (Dussel, 1994).

Sin título (1981) es la última obra del pintor argentino Antonio Berni, inconclusa, que él había planteado como un homenaje amoroso a su última modelo y que, sin embargo, decidió cambiar totalmente en sus últimos días: "lo que había sido ella misma tirada en una playa soleada unos días antes, se había convertido ahora en una escena nocturna sombría, con un cuerpo pálido sobre la arena oscura” (Pérez Bergliaffa, 2010). Como los sujetos-autómatas de los lienzos de Hopper, tampoco los individuos de las obras de Berni tienen expectativas y, en el caso de los sujetos de la

6 Por razones de espacio, y también porque el texto "Vida de Juanito Lagunas" (Bagué Quílez, 2014,21 ) puede leerse desde una perspectiva de mecanización de la humanidad, más que de violencia de la dictadura argentina, analizaremos este poema en trabajos futuros. 
historia argentina simbolizados por la mujer desnuda de la obra Sin titulo -tan cerca de la postura de la Olympia de Manet y tan tremendamente lejos del universo erótico desplegado por el cuadro impresionista-, se ven despojados de cualquier identidad, de cualquier deseo y, con los vuelos de la muerte, incluso de la conciencia de su propia muerte, el último reducto de su humanidad. Como relata Luis Bagué Quílez en la primera estrofa del poema ecfrástico elaborado a partir de la experiencia visual de la exposición sobre Berni, son cuerpos que solo tienen conciencia de su cuerpo:

Aerolíneas argentinas

Sin título. 1981

Este cuerpo yacente,

bañado por la luna del océano,

solo tiene conciencia de su cuerpo.

El humo negro y gris del aeroplano

traza en el aire un signo

de admiración,

y deja atrás la costa como un bosque

entre llamas.

La narración afirma

que los muertos no mueren. Los desaparecidos

se limitan a desaparecer

en playas siderales

bajo la alfombra de los continentes.

Cierra los ojos: cuenta

hasta cien

veces lo que has visto. 
Texto y textura: el Principio ecfrástico en PASEO DE LA IDENTIDAD de Luis Bagué Quílez

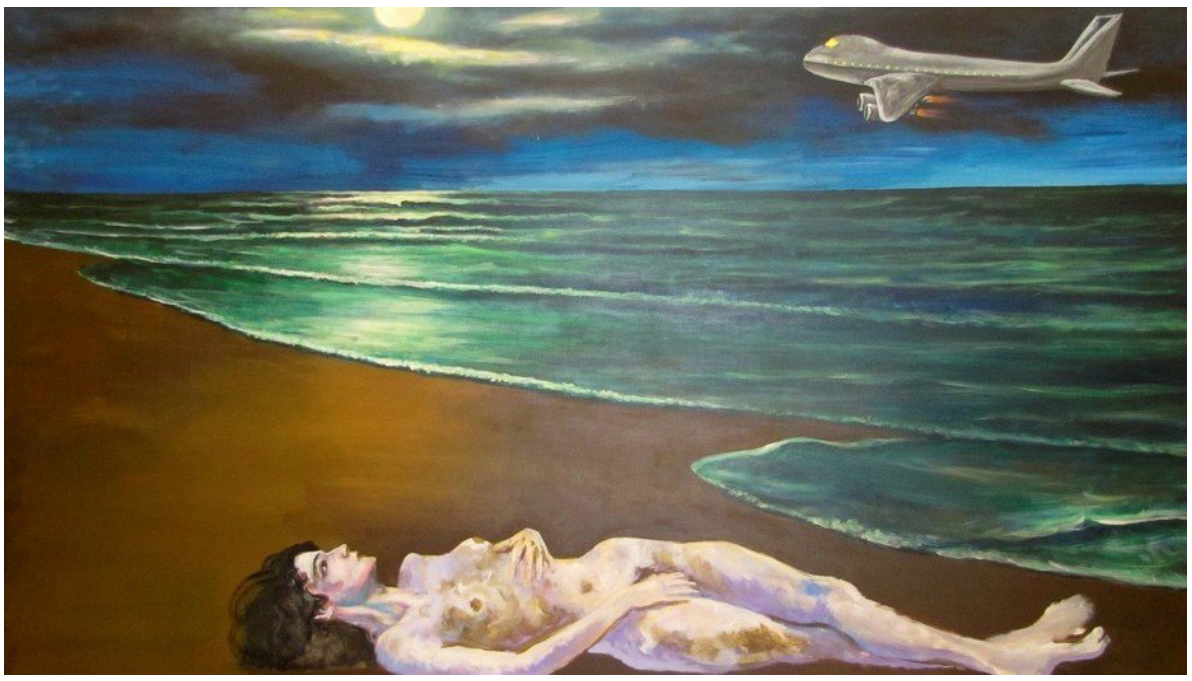

Figura 7 - Antonio Berni, Sin título, 1981

Óleo y acrílico sobre lienzo. $160 \times 200 \mathrm{~cm}$

Fuente: Centro Virtual de Arte Arsentino

Los vuelos de la muerte planean, sobre el texto y la textura y a las tres primeras estrofas de descripción ecfrástica, el poeta, como ya nos ha acostumbrado, añade su parte narrativa que explica en el apartado de su Menina ante el espejo al "describir el infierno":

A veces, aproximarse a la superficie permite entender el fondo. En este caso, la forma y el fondo interrogan al espectador y le reclaman la responsabilidad de enfrentarse al vacío. Solemos representar a la muerte con los párpados cerrados, con esa placidez lejana que poseen quienes han cruzado el umbral de lo visible. Por eso nos perturba el vidrio constelado de unos ojos que han contemplado el rostro del horror sin dejar de contemplar el cielo. (Bagué Quílez, 2016, 30). 
Desde la misma óptica de la desaparición, tanto Antonio Berni como Luis Bagué vuelven a interrogarse sobre la legitimidad del arte para desvelar lo que no queremos ver o sobre lo que el horror no nos permite verbalizar. Ocurre en el poema "Crucificción" (2014, 22), evidente desautomatización del término 'crucifixión' que anticipa la intervención narrativa en la práctica ecfrástica, correspondiente al lienzo Cristo en el garage (1981) del pintor argentino:

\author{
Crucificción \\ Enigma del taller. \\ Una motocicleta rescatada del óxido \\ no pertenece a nadie. \\ El tragaluz, un cielo entre barrotes. \\ Desde un ángulo, muerto nos observa \\ este Cristo doméstico. \\ Cal viva y electrodos. \\ Una gota de sangre en el garaje. \\ Ha vuelto a casa.
}

(Bagué Quílez, 2014, 22)

También en este caso, el poeta ofrece una interpretación ensayística del óleo y de la voluntad del pintor de retratar a Cristo con cierta ambigüedad:

Según la ortoxodia cristiana, anuncian el mensaje de que Jesucristo está presente en todos los hogares. De hecho, Berni empleó como decorado los dos lugares más significativos de su intimidad: su piso (en Cristo en el departamento) y su taller (en Cristo en el garage). Sin embargo, desde una perspectiva histórica, estas dos lecciones de anatomía [...] compara[n] el 
cuerpo doliente de Jesucristo con los cuerpos torturados y [...] establece[n] una analogía entre el Mesías y los desaparecidos durante la dictadura. [...] El mismo título de Cristo en el garage podría aludir al ominoso Garage Olimpo, un centro clandestino de detención situado en las afueras de Buenos Aires, en el que fueron torturadas o asesinadas cerca de setecientas personas entre agosto de 1978 y enero de 1979. (Bagué Quílez, 2016, 32-33).

El poeta adhiere a esta reproducción ambigua de Cristo desde el término "enigma” con el que encabeza su texto y, después de una breve écfrasis descriptiva, subvierte el recorrido de la mirada atribuyéndole a Cristo la visión de la escena que, en realidad, solo le puede pertenecer al observador, puesto que el protagonista de la tela tiene los ojos cerrados. Una vez más se establece un juego de espejos gracias al cual el ser humano se ve reflejado en la corporeidad de un cadáver y en la mirada de Cristo de la que no nos podemos salvar. Hay que leer esta imposibilidad de salvación del juicio cristiano en clave de una ironía que "baja a su infierno descarnado”, en palabras de Luján Atienza (2016, 170), ya que no se puede olvidar la relación entre los sectores menos contestatarios de la institución eclesiástica y la cúpula militar del golpe argentino. El verso "Cal viva y electrodos" (v. 7) delata la intención de Luis Bagué de recrear el universo y los instrumentos de tortura del Garage Olimpo porque, en la pintura de Berni, esos elementos no aparecen, a pesar de ser objetos que tranquilamente podrían formar parte de los utensilios de un taller. El tremendo silencio de la violencia dictatorial se condensa en una única gota de sangre (v. 8), referencia cromática a la sangre que está coagulándose a los pies de Cristo como en un tarro de barniz roja. 


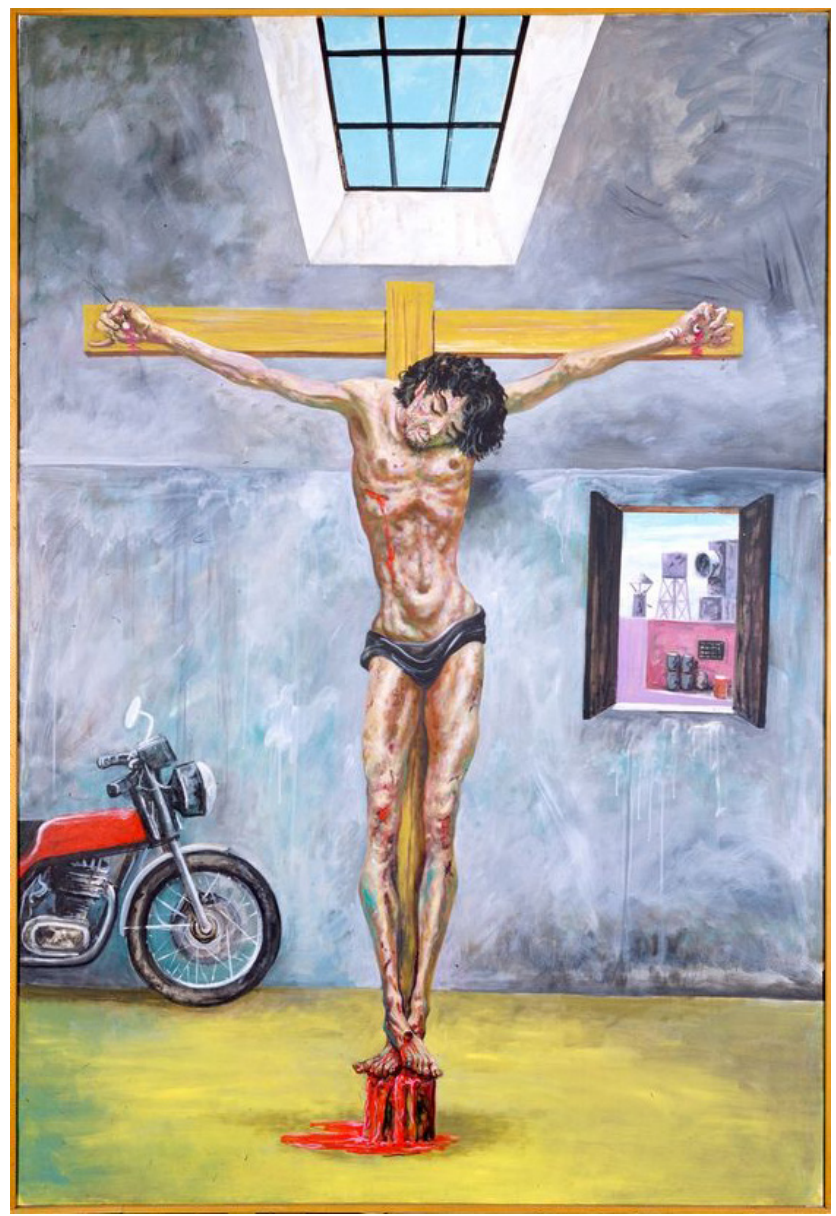

Figura 8 - Antonio Berni, Cristo en el garage, 1981

Óleo sobre lienzo. 200 x $135 \mathrm{~cm}$

Fuente: Centro Virtual de Arte Arsentino 


\section{Regreso a Europa y al "origen del mundo"}

"Hemos visto ya tantas y tantas atrocidades, que a veces no sabemos si las estamos contemplando en una película o en un informativo", comenta Luis Bagué en una entrevista de 2018 a cargo de Antonio Arco (Bagué, 2018). El poeta, cinéfilo apasionado cuya primera vocación fue ser director de cine (Bagué, 2018), sigue demostrando en la tercera y última sección del poemario, "Escala real", que la mirada es una de sus primeras fuentes de inspiración. Los fotogramas que se quedan en su retina de poeta y que transfiere al papel tienen un enfoque fílmico, con una adherencia a este medio más evidente aún en "Tríptico Lumière", serie de tres poemas que abre la última sección y que coloca al lector en el ambiente europeo y en el momento de estreno del séptimo arte. Nos adentraríamos, por lo tanto, en la écfrasis fílmica, pero dejaremos este análisis para un trabajo más extenso y centrado en lo puramente cinematográfico, ya que Luis Bagué dedica muchos poemas más a lo fílmico e incluso un entero poemario, Babilionia, mon amour (2005), escrito a cuatro manos con Joaquín Juan Penalva. Sin embargo, este tríptico nos interesa para seguir profundizando el discurso sobre la modernidad y las reflexiones de Bagué Quílez acerca de la multitud, "muchedumbre al servicio de la industria” $(2014,39)$ que se desplaza en un bullicioso silencio7. El cine mudo de los hermanos Lumière -que, en el momento del estreno de sus productos, no confiaban demasiado en el medio ("Le cinéma est une

7 "El ensayo de Baudelaire [El pintor de la vida moderna (1863], habla de la función del artista moderno y de su papel de observador en medio de la multitud [...] para ofrecer una definición imprescindible de la modernidad: 'La modernidad es lo transitorio, lo fugitivo, lo contingente, la mitad del arte, cuya otra mitad es lo eterno y lo inmutable” (Jiménez Millán, 2014, 158). 
invention sans avenire”, señala irónicamente Bagué Quílez en el epígrafe al tríptico) - permite aprender a caminar junto a la imagen, parafraseando un verso del texto ${ }^{8}$, es decir, extender el concepto de percepción de la imagen a una imagen en movimiento, nada descontado en el final del siglo XIX en que se coloca Luis Bagué y que tanto aterrorizó a quienes, por primera vez, vieron un tren en una pantalla que parecía a punto de atropellarlos. Para mantenernos la coherencia respecto al tema de la identidad moderna, leída a través de la galería personal de Luis Bagué, leemos la referencia a las películas que inauguran la historia del cine como el enlace con imágenes que, por primera vez, ponen en evidencia y en movimiento un extraño género de subjetividad, en opinión de Rushton:

una subjetividad sin contexto ni telón de fondo, una subjetividad que vive enteramente en el presente, como si estuviera reaccionando y respondiendo únicamente a los eventos fílmicos así como ocurren. Si estas son imágenes subjetivas, desde luego no son imágenes guiadas por un sujeto. Más bien, son la respuesta a un sujeto que ha perdido toda su subjetividad, que ha perdido cualquier rasgo de agencia y autodeterminación. (Rushton, 2008, 128 [traducción mía])

Es un tipo de sujeto que encuentra un lugar perfecto en el paseo de la identidad que estamos recorriendo y que, siguiendo en el viejo continente, nos conduce a dos obras de arte más, Venere degli stracci (1967) de Michelangelo

8 "De la quietud Daguerre / al vértigo inflamable del nitrato de plata / no media más que un paso. Aprendo a caminar / junto a la imagen. Pulso pausa" (2014, 39, vv. 6-9). Con las referencias cinematográficas, no solo se ensancha el medio artístico, sino también los procedimientos ecfrásticos porque se produce una transición del régimen semiótico de movimiento/imagen al régimen de tiempo/imagen, que, por supuesto, implica una reflexión poética más profunda (cfr. Deleuze, 1987). 
Texto y textura: el Principio ecfrástico en PASEO DE LA IDENTIDAD de Luis Bagué Quílez

Pistoletto y El origen del mundo (1866) de Gustave Courbet, poetizadas en sendos textos por Bagué Quílez en el díptico "Arte pobre”.

\author{
Ropa tendida \\ (Venere degli stracci) \\ La Venus de los trapos \\ reclama su vitrina \\ en el archivo cultural: \\ un Sinaí desgarrado en jirones.
}

Desembocan aquí cambios de temporada,

cazadoras que oscilan en la horca de un perchero, irreductibles lázaros

esperando la hora de su resurrección.

Noli me tangere.

Pero tender la ropa es un acto profano, aunque requiera cierto recogimiento.

El blanco nuclear de Zurbarán.

Hay ropa tendida. Silencio.

Venus admira la colada inmensa.

El andrajo y el mármol

frente a frente.

Existen obras que adquieren carácter simbólico y que, por lo tanto, pasan a formar parte del archivo cultural (v. 3), más allá de la voluntad del artista, lo afirma Luis Bagué con rotundidad: es la Venus de los trapos quien 
reclama ese sitio. Esta instalación se ha vuelto icónica no solo en el seno del arte pobre, sino también de nuestra contemporaneidad precisamente gracias a la presencia de los trapos: la nuestra, en que sigue paseándose la identidad, es una época que está consumiendo la propia realidad y, al mismo tiempo, la obra sigue teniendo la belleza de la obra de arte, que “nunca será soluble", recordando la afirmación con la que empezaba este recorrido artístico de Luis Bagué Quílez. El enfrentamiento entre la belleza insoluble, duradera, y la corrupción del consumo ("El andrajo y el mármol / frente a frente", vv. 16-17) estimula el sentido dinámico que impulsa la imaginación, que instala la figura femenina en el contexto desacralizado y en el campo semántico de una tienda de ropa ("vitrina”, v. 2; "cambio de temporada”, "cazadoras", "perchero”, vv. 5-7) o de la gestión doméstica de la colada (vv. 14-15). Asistimos una vez más a una disposición de los elementos poéticos que replica la colocación espacial de la obra de arte: en la instalación de Pistoletto, en la que los trapos van cambiando según el espacio expositivo que la acoge, la figura de Venus está de espaldas como si estuviera contemplando una multiplicidad de prendas potencialmente interminables - una multiplicidad en forma de altura, para ser más exactos y para configurar la imagen del Sinaí del cuarto verso- y produciendo una polaridad dialéctica parecida a la que caracteriza a las pinturas de espejo. El ojo del observador nota primero la protagonista de la instalación, para pasar después a los dos lados de consumismo prêt-à-porter que la rodean y para volver, finalmente, a la parte central de la obra y contemplar el enfrentamiento de las dos polaridades simbólicas. 
Texto y textura: el Principio ecfrástico en PASEO DE LA IDENTIDAD de Luis Bagué Quílez

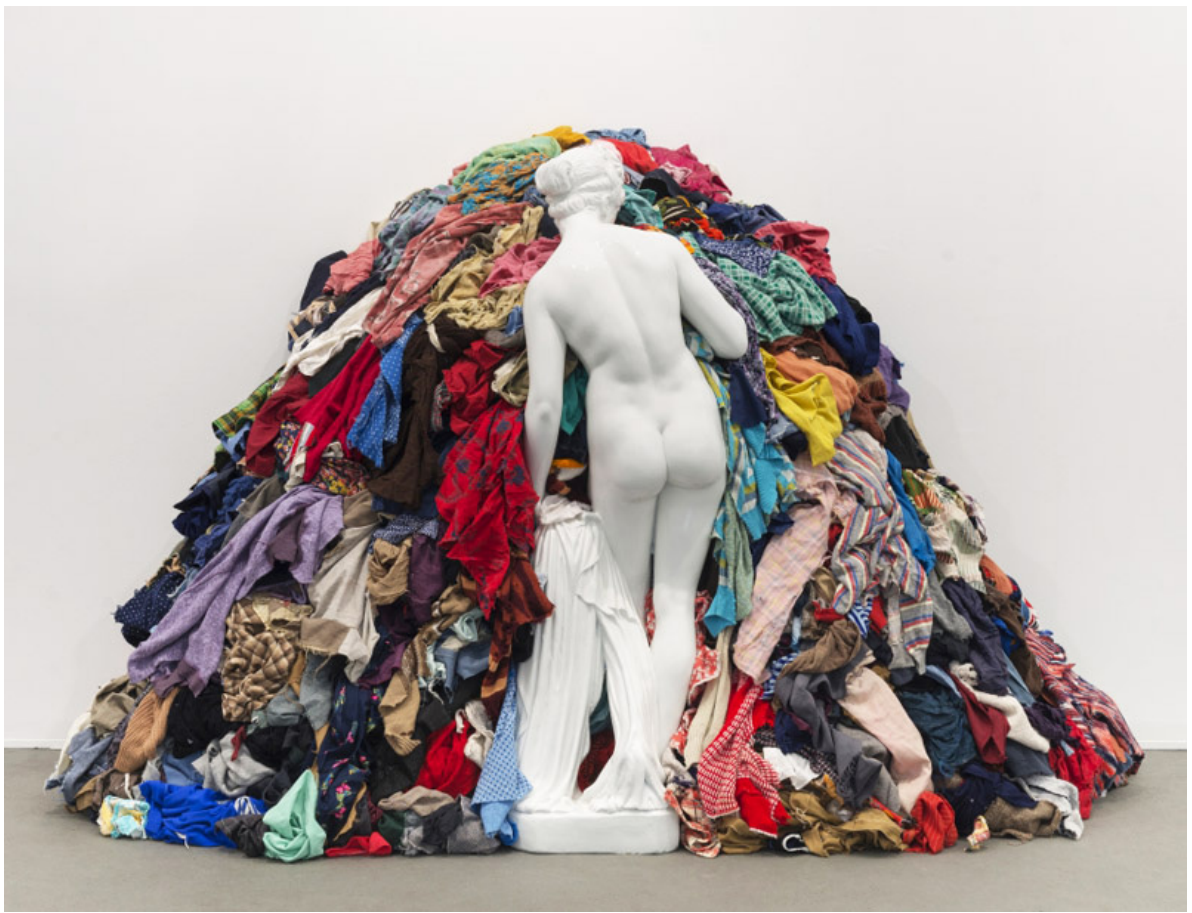

Figura 9 - Michelangelo Pistoletto, Venus de los trapos, 1967

Fuente: Museo de Arte Contemporáneo del Castillo de Rívoli

En su texto, Luis Bagué Quílez procede de la misma manera: "La Venus de los trapos" (v. 1) se presenta al lector reclamando su sitio no solo en el poema, sino en la historia del arte y de los ideales de belleza. Se crean después dos partes simétricas (vv. 5-7 y 14-15) dedicadas a la cotidianidad y al consumismo que difuminan suavemente hacia los versos centrales del poema, que, en cambio, vuelven a otorgar protagonismo y sacralidad a la figura neoclásica gracias a la exaltación de su blancura y a las referencias intertextuales e intermediales al 
episodio bíblico de la resurrección de Lázaro y a dos universos artísticos más: las transposiciones pictóricas derivadas de la resurrección de Cristo y del famoso "Noli me tangere" y las pinturas de Francisco de Zurbarán, nuclearizadas en la fuerza visual del blanco que en ellas domina.

En la pintura de espejos hay dos elementos: por un lado está el estático de la memoria y por el otro el espejo que el artista coloca enfrente de ella y que, en la Venere degli stracci, es el presente material del consumismo, no solo de ropa o de objetos materiales, sino también de imágenes (mientras que la imagen neoclásica de Venus ya forma parte del archivo cultural de nuestra retina) ${ }^{9}$. El espejo consume y desgasta las imágenes y luego las repropone como imágenes nuevas, "resuscitadas" gracias a la relación entre lo estático de la memoria y el movimiento continuo del cambio. Como en el caso de la referencia a la Gasolinera de Hopper, gracias a la relación ecfrástica entre texto y obra de arte en este poema, también se produce una metaforización espacial de lo verbal.

Terminamos este recorrido artístico paralelo al "paseo de la identidad" con un último poema ecfrástico que sugiere una vuelta a los orígenes perdidos de la humanidad, cerrando el círculo con la referencia a los murales de Puerto Iguazú que han inaugurado el camino. Junto con Ropa tendida (Venere degli stracci), el poema Umbilical $(2014,50)$ forma el díptico "Arte pobre" y el subtítulo nos aclara la referencia a la pintura El origen del mundo (1866) de Gustave Courbet.

9 La Venus de la instalación de Pistoletto es una reproducción de la escultura Venus con manzana (c. 1805) de Bertel Thorvaldsen. 


\section{Umbilical}

(Lorigine du monde)

Algo nos une:

la gravedad del mundo en carne viva.

El principio o el fin, según se mire,

bajo capas de trementina y óleo.

Prefiero la elocuencia de lo insignificante:

un sexo sin contexto

es el lenguaje en sí mismo, presencia revelada.

La vulva-corazón y el ojo-falo.

Gónadas entusiastas. Un ovario de luz.

Algo nos diferencia.

Mi forma de perder tiempo mirándote, el aspecto verbal de tu desnudo.

(Bagué Quílez, 2014, 50)

La referencia a uno de los padres de la pintura realista cierra el paseo visual de la identidad y sugiere que, más que la identidad en sí o su búsqueda, lo que caracteriza al ser humano es su existencia "en carne viva” (v. 2). El tránsito por el mundo no es más que el rastro de una presencia física que, sin embargo, puede cubrirse y adquirir una significación más duradera que la contingencia bajo "capas de trementina y óleo" (v. 5). Hay que recordar que los poemas del díptico "Arte pobre" se introducen con el epígrafe de Germano Celant, "un'arte povera, impegnata con la contingenza" (2014, 51). Desde la tercera estrofa del poema se propone una teorización en verso del 
procedimiento ecfrástico por medio de la alusión al desvelamiento del sexo de la tela de Courbet. Sin embargo, tanto en el cuadro como en el poema, hay algo más que la provocación de su inmediatez:

su novedad consiste [...] en quebrantar el espacio pictórico tradicional haciendo que sea el propio cuerpo femenino el que estructure el propio espacio pictórico. No hace falta escenografía, tampoco contexto o correlato natural, porque es el cuerpo el que organiza su entorno con una presencia que va más allá del erotismo como espectáculo [...]. El cuerpo femenino deja de ser un objeto agradable dimensionado por un contexto que le es exterior e identificado por la belleza como síntoma y aparece con toda su plenitud" (Bosco Díaz-Urmeneta Muñoz, 1999, 66).

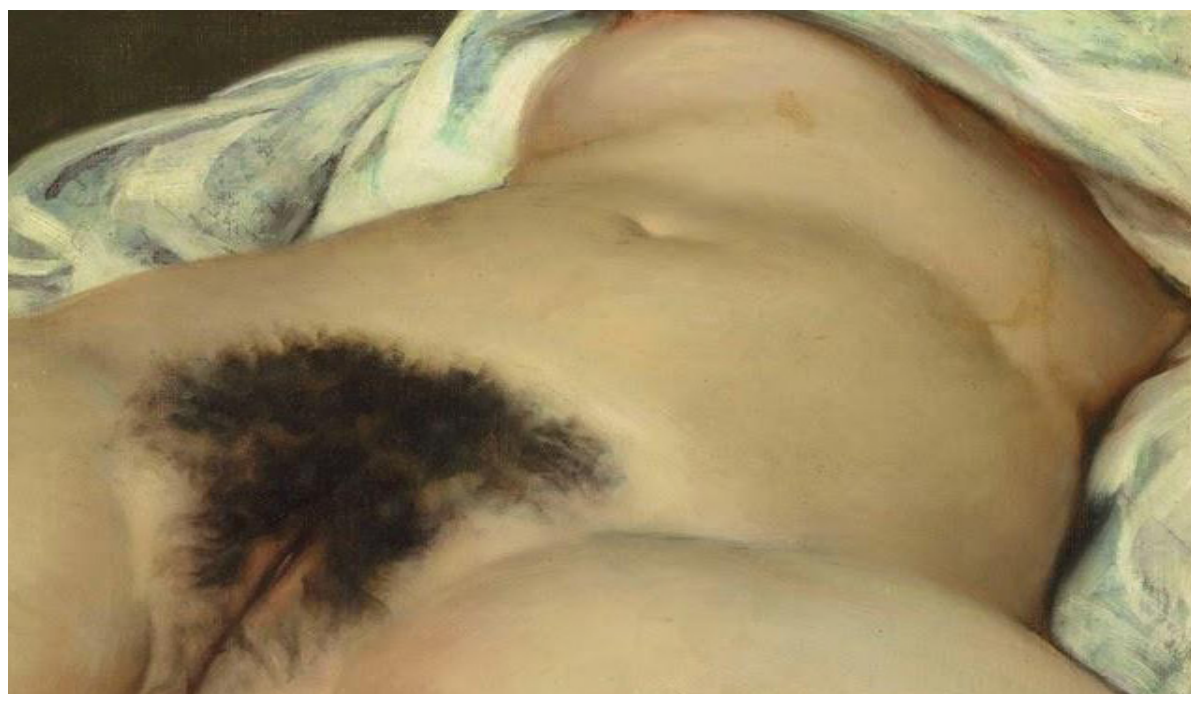

Figura 10 - Gustave Courbet, El origen del mundo, 1866

Óleo sobre lienzo. 46 × $55 \mathrm{~cm}$ Fuente: Musée d'Orsay 
Es la disposición del cuerpo y no su evocación lo que crea una imagen plena. La interpelación -y no la exposición- de este espacio energético es lo que acomuna el óleo de Courbet y el poema de Bagué Quílez, quien subraya la necesaria falta de contexto para otorgarle una dimensión verbal -y permanente- a lo fugaz de la contingencia. A través de la referencia al principio ecfrástico, vuelven a coincidir la dimensión verbal y espacial de la poesía con lo temporal del arte figurativo y, tal y como Courbet interpela, el espacio sexual que origina el mundo, también la voz poética de Bagué Quílez interpela lo figurativo en su totalidad adelantando la existencia de la dimensión verbal que encierra en si. Si en el lienzo tan realista de Courbet puede leerse el simbolismo de un regreso al útero (recordemos lo "umbilical" del título del poema), en este recorrido simbolista de vuelta también podemos individuar un doble movimiento hacia fuera y hacia dentro del cuadro, saliendo de los límites de lo puramente figurativo y adentrándose en la forma espacial de la literatura.

\section{CONCLUSIONES}

En Paseo de la identidad, gracias al gran número de poemas elaborados según el principio ecfrástico, Luis Bagué Quílez amplía su indagación poética a nuevos territorios, por los que transita acompańado por obras de arte hacia la búsqueda de la humanidad moderna. Las referencias artísticas no suponen un análisis exacto o una descripción objetiva, sino que el poeta se basa en ellas como puntos de partida para que cumplan una determinada 
función en el contexto literario en el que aparecen y, en este sentido, tiene un "efecto de realidad" (Riffaterre, 2000, 162).

La identidad -y la humanidad- se lee en este poemario a través del filtro del arte realista, ya sea el realismo americano de Edward Hopper, el Nuevo Realismo de Antonio Berni o el realismo más tradicional de Gustave Courbet, pero, como en el caso de las películas de los hermanos Lumière, es un realismo que crea sujetos instalados en un presente perpetuo que, con los versos de Bagué Quílez, rompen los límites miméticos del medio artístico abarcando la experiencia del observador/lector. El principio ecfrástico que se emplea en este poemario hace del poema un lugar en el que se resuelve la dualidad entre tiempo y espacio que existe entre texto e imagen, proporcionando una reflexión sobre la identidad con la que también se mide la distancia entre individuo y ser humano.

\section{REFERENCIAS BIBLIOGRÁFICAS}

Abril, Juan Carlos. “Reseña de Paseo de la identidad”. In: Lectura y signo, 9, 2014, 127-129.

Bagué Quílez, Luis. Telón de sombras. Madrid: Hiperión, 2002.

Bagué Quílez, Luis. Paseo de la identidad. Madrid: Visor, 2014.

Bagué Quílez, Luis. La Menina ante el espejo. Visita al museo 3.0. Madrid: Fórcola, 2016.

Bagué Quílez, Luis. Clima mediterráneo. Madrid: Visor, 2017. 
Bagué Quílez, Luis. “Luis Bagué. Un poeta y su mar. Entrevista a cargo de Antonio Arco". In: La Verdad, 22/10/2018. Disponible en: <https://www.laverdad.es/ ababol/literatura/luis-bague-poeta-20181020214138-nt.html>. Acceso: 23 jul. 2020.

Bagué Quílez, Luis; Penalva, Joaquín Juan. Babilonia, mon amour. Murcia: Universidad de Murcia, 2005.

Baños Saldaña, José Ángel. Desautomatización y posmodernidad en la poesía española contemporánea: La tradición Grecolatina y la Biblia. Córdoba: Editorial Universidad de Córdoba, 2019.

Bosco Díaz-Urmeneta Muñoz, Juan. "El pintor del cuerpo. Notas sobre la modernidad de Gustave Courbet”. In: Romero de Solis, Diego; Bosco DíazUrmeneta Muñoz, Juan; López Lloret, Jorge (org.). Variaciones sobre el cuerpo. Sevilla: Universidad de Sevilla, 1999, 45-68.

Carbajosa Palmero, Natalia. "La écfrasis en la obra de Luis Javier Moreno". In: Revista Signa, 22, 2013, 205-226.

Deleuze, Gilles. La imagen-tiempo. Estudios sobre cine II. Barcelona/Buenos Aires/ México: Paidós, 1987.

Díaz de Castro, Francisco; Del Olmo Iturriarte, Almudena (orgs.). Écfrasis e imitación artística en la poesía hispánica contemporánea. Sevilla: Renacimiento, 2012.

Deleuze, Gilles. La imagen-tiempo. Estudios sobre cine II. Barcelona/Buenos Aires/ México: Paidós, 1987.

Díez de Revenga, Francisco Javier. "Signos, marcas e iconos de la modernidad en la poesía rebelde e irónica de Luis Bagué”. In: Versants, 64.3, 2017, 155-123.

Dussel, Enrique. “Crítica del 'Mito de la Modernidad””. In: 1492. El encubrimiento del otro. Hacia el origen del "Mito de la modernidad". La Paz: Plural Editores, 1994. 
Fernández Klohe, Carmen. El imperativo ekfrástico en la prosa de Ramón Gómez de la Serna. Nueva York: Monografías de ALDEEU, 2001.

Fernández Mallo, Augustín. Teoría general de la basura (cultura, apropiación, complejidad). Barcelona: Galaxia Gutenberg, 2018.

García Martínez, Luis Francisco. La ékfrasis en la poesía contemporánea española: de Ángel González a Encarnación Pisonero. Madrid: Devenir, 2011.

Hagstrum, Jean. The sister arts. The tradition of literary pictorialism and English poetry from Dryden to Gray. Chicago: University of Chicago Press, 1958.

Heffernan, James A. W. Museum of Words. The Poetics of Ekphrasis from Homer to Ashberry. University of Chicago Press, 1993.

Jiménez Millán, Antonio. "Modernidad y síntesis de las artes". In: Litoral. "Museum: la pintura escrita", 258, 2014, 156-168.

Krieger, Murray. "Ekphrasis and the Still Movement of Poetry; or Lackoon Revisited". In: McDowell, Frederick P. W. (org.). The Poet as Critic. Evanston: Northwestern University Press, 1967, 3-26.

Krieger, Murray. Ekphrasis. The Illusion of a Natural Sign. Baltimore: Johns Hopkins UP, 1992.

Lessing, Gotthold Ephraim. Laocoonte o sobre los limites en la pintura y la poesía. México: UNAM, 1960.

Luján Atienza, Ángel Luis. "Reseña de Paseo de la identidad". In: Paraíso: revista de poesía, 12, 2016, 169-172.

Melville, Herman. Moby Dick. Madrid: Círculo de Lectores, 1994.

Mignolo, Walter. "Aiesthesis decolonial”. In: Calle 14. Revista de investigación en el campo del arte, 4.4, 2010, 10-25.

Mitchell, William John Thomas. Iconología. Imagen, texto, ideología. Buenos Aires: Capital Intelectual, 2016. 
Mitchell, William John Thomas. ¿Qué quieren las imágenes? Una crítica de la cultura visual. Vitoria-Gasteiz: Sans Soleil, 2017.

Montiel, Juan Antonio. "Prólogo". In: Strand, Mark. Hopper. Barcelona: Lumen, 2008 [2004], 6-10.

Moretti, Franco. "The dialectic of fear". In: New Left Review, 136, 1982, 67-85.

Pérez Bergliaffa, Mercedes. "El último amor de Antonio Berni". In: Clarín. Cultura, 10/07/2010. Disponible en: <https://www.clarin.com/cultura/76-30-bernicreo-ultimo-amor_0_rJo0lq-BW.html>. Acceso: 22 jul. 2020.

Publio Virgilio Marone, Eneida. Edición y traducción de Alfonso Cuatrecasas. Madrid: Austral, 2012.

Riffaterre, Michael. "La ilusión de la écfrasis". In: Monegal, Antonio (org.). Literatura y pintura. Madrid: Arco Libros, 2000, 161-183.

Rodríguez Herrera, José Manuel. "El capitán Ahab frente al enigma del abismo: el valor de los símbolos en Moby Dick". In: Amerika, 11, 2014. Disponible en: <https://journals.openedition.org/amerika/5620?lang=en>. Acceso: 23 jul. 2020.

Rushton, Richard. "Passions and actions: Deleuze’s cinematographic Cogito". In: Deleuze Studies, 2.2, 2008, 121-139.

Shannon, Joshua. The recording machine: art and fact during the cold war. New Haven/Londres: Yale University Press, 2017.

Strand, Mark. "Edward Hopper". In: Encyclopaedia Britannica. Disponible en: $<$ https://www.britannica.com/biography/Edward-Hopper>. Acceso: 22 jul. 2020 .

Strand, Mark. Hopper. Barcelona: Lumen, 2008. 
